Supplementary material

\title{
Sensitive metal oxide-clay nanocomposite colorimetric sensor development for aflatoxin detection in food: corn and almond
}

Nishtha Khansilia, Prayaga Murali Krishna, ${ }^{\text {a, }}$

a Department of Basic and Applied Science, National Institute of Food Technology Entrepreneurship and Management (NIFTEM), Haryana 131028, India

* Corresponding author: physicsres.niftem@gmail.com (Prayaga Murali Krishna) 
Optimization of experimental conditions

(a) The concentration of $\mathrm{ZnOBt}$

The concentration of zinc bentonite has significant role on the binding of AFs derived phenolate anions $[1,2]$ to the composite Cur- ZnBt. Thus, the concentration of ZnBt was optimized in the visual method. As described above Cur- ZnBt -AF has absorption band at 367 $\mathrm{nm}$. So the increase in absorbance at $367 \mathrm{~nm}$ was calculated to know the degree of AFs binding to the composite. A higher absorbance indicates higher binding. The concentration of $\mathrm{ZnBt}$ was optimized from $0.1 \mathrm{mg} / \mathrm{ml}$ to $1 \mathrm{mg} / \mathrm{ml}$, the plot of absorbance at $367 \mathrm{~nm}$ versus the $\mathrm{ZnBt}$ concentration in the suspension was calculated as shown in Supplementary material (Figure $\mathrm{S} 1)$. The $\mathrm{A}_{367}$ value increased sharply in the concentration of $\mathrm{Zn}-\mathrm{Bt}$ range from $0.1 \mathrm{mg} / \mathrm{ml}$ to $0.45 \mathrm{mg} / \mathrm{ml}$ and reached a maximum when the concentration is $0.478 \mathrm{mg} / \mathrm{ml}$. Thus, $0.5 \mathrm{mg} / \mathrm{ml}$ $\mathrm{ZnBt}$ that ensured improved binding strong enough in the composite $\mathrm{ZnBt}-\mathrm{Cur}$ was selected in our experiment.

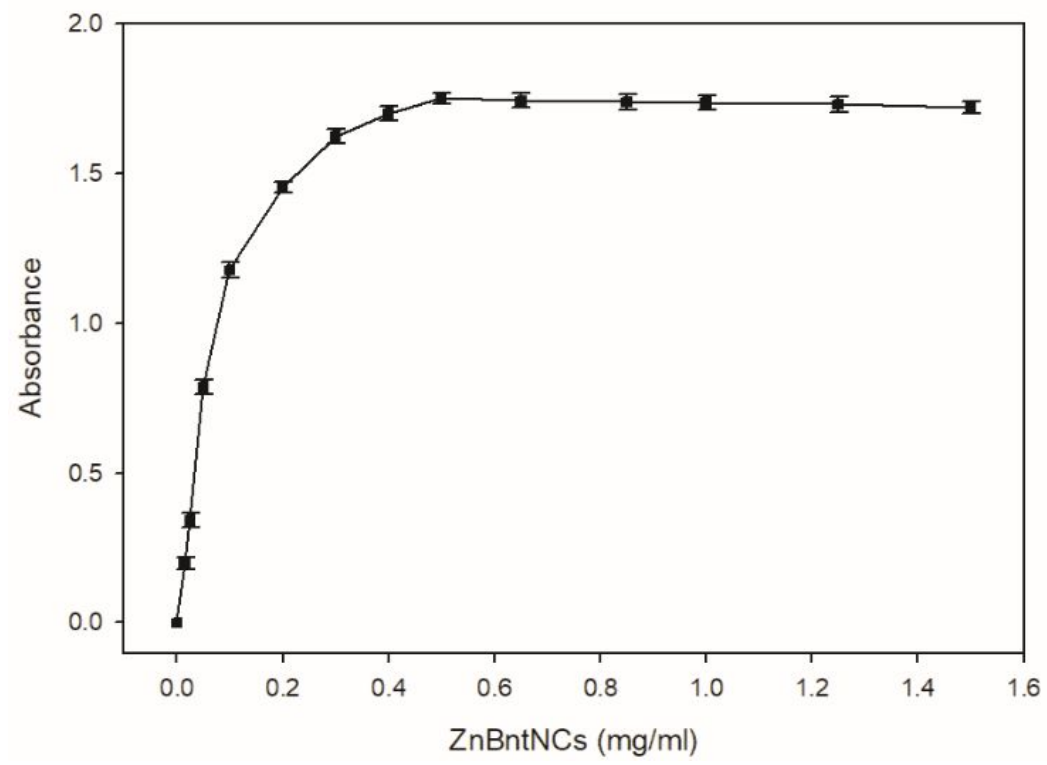

Figure S1. Effect of modified concentration of $\mathrm{ZnBt}$ on the binding of AFs phenolate anions to ZnBt-Cur composite.

(b) Concentration of curcumin

To achieve the best sensing performance, the concentration of curcumin was further standardized. Figure S2 shows the photographic image of Cur-ZnBt in the presence of AFs at different concentration. It is evident that $\mathrm{ZnBt}$ does not alone bind to AFs if the concentration of Cur drops below $0.5 \mathrm{mg} / \mathrm{ml}$. On the other hand, binding reached maxium if the concentration is increased to $1 \mathrm{mg} / \mathrm{ml}$ or higher. This is accompanied by color change from red to orange. However, by decreasing the amount of curcumin, sensitivity of the method will be increased. In other words, high concentration of curcumin consumes more AFs and have an adverse effect on sensitivity. Therefore, the concentration of curcumin at $1 \mathrm{mg} / \mathrm{ml}$ was chosen in our study. 


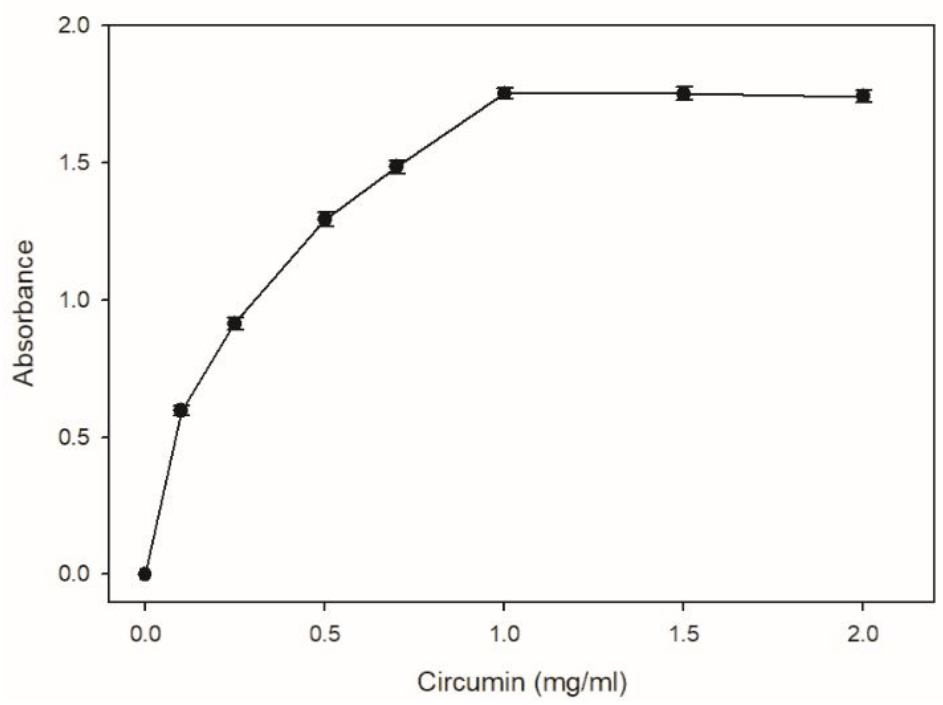

Figure S2. The binding of $\mathrm{Zn}-\mathrm{Bt}$ using curcumin $(1 \mathrm{mg} / \mathrm{ml})$ as mediator to AFs.

(c) Effect of $\mathrm{NaOH}$

To understand whether alkali induce binding of Cur-ZnBt, $\mathrm{A}_{367}$ measurement of Cur-ZnBt in presence of different $\mathrm{NaOH}$ concentration was performed. As shown in Figure $\mathrm{S} 3, \mathrm{~A}_{367}$ value increased steadily till $0.05 \mathrm{M}$, while it became constant for no change beyond $1 \mathrm{M}$ even after $5 \mathrm{~min}$ of reaction. Therefore, we try to avoid the possible saturation effect of $\mathrm{NaOH}$ on Cur$\mathrm{ZnBt}$ and fixed the concentration of $\mathrm{NaOH}$ as $1 \mathrm{M}$.

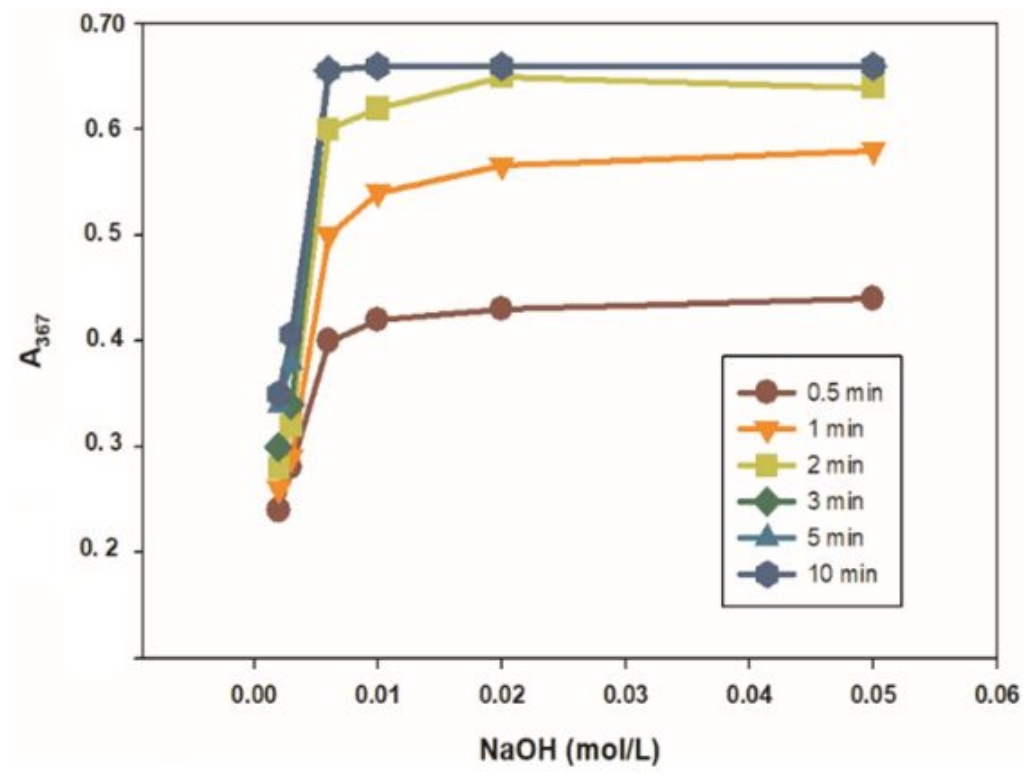

Figure S3. $\mathrm{A}_{367}$ measurement of Cur- $\mathrm{ZnBt}$ in presence of different $\mathrm{NaOH}$ concentration

(d) Incubation time 
The effect of incubation time on the colorimetric response was also investigated. Figure S4 shows the binding of Cur- $\mathrm{ZnBt}$ with $\mathrm{AFs}$ at different $\mathrm{pH}$. The effect of $\mathrm{pH}$ at 9.24 was maximum showing maximum value at $A_{367}$. This effect was found increasing in the initial 2 minutes of the reaction. Thereby, constant value of $\mathrm{A}_{367}$ after 2 minutes showed saturation of the bond. Thus initial 2-3 minutes are chosen as the optimized time of incubation and for taking the final measurement at $\mathrm{A}_{367}$ as estimated time for the bond formation between AFs and Cur-ZnBt composite.

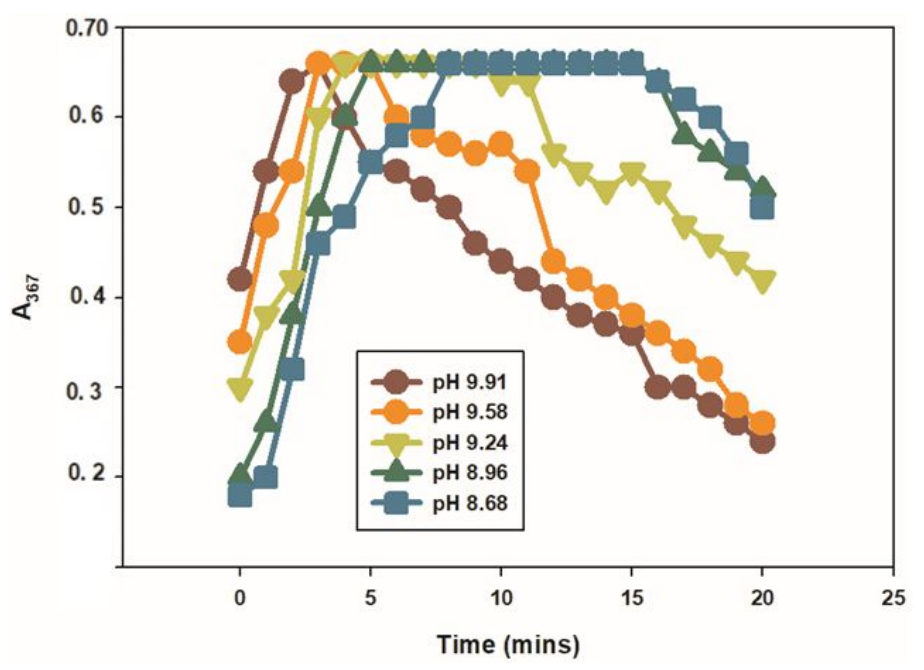

Figure S4. $\mathrm{A}_{367}$ value of $\mathrm{ZnBt}$ containing curcumin $(1 \mathrm{mg} / \mathrm{ml})$ versus time at different $\mathrm{pH}$. (The data were recorded at the interval of $1 \mathrm{~min}$ ).

Table S1. AFs detection in food samples from local and commercial market.

\begin{tabular}{llll}
\hline Sample no. & $\begin{array}{l}\text { Cur-ZnOBt Detection } \\
(\mathrm{ppb})\end{array}$ & $\begin{array}{l}\text { LC/MS-MS detection } \\
(\mathrm{ppb})\end{array}$ & $\begin{array}{l}\text { Accuracy } \\
(\%)\end{array}$ \\
1 & & & \\
2 & 0 & $\mathrm{ND}$ & - \\
3 & 0 & $\mathrm{ND}$ & - \\
4 & 0.2 & $\mathrm{ND}$ & - \\
5 & 2.74 & 2.64 & 96.21 \\
6 & 4.28 & 4.02 & 93.54 \\
7 & 5.35 & 5.1 & 95.09 \\
8 & 10 & 8.8 & 86.4 \\
9 & 3.19 & 3.08 & 96.43 \\
\hline
\end{tabular}



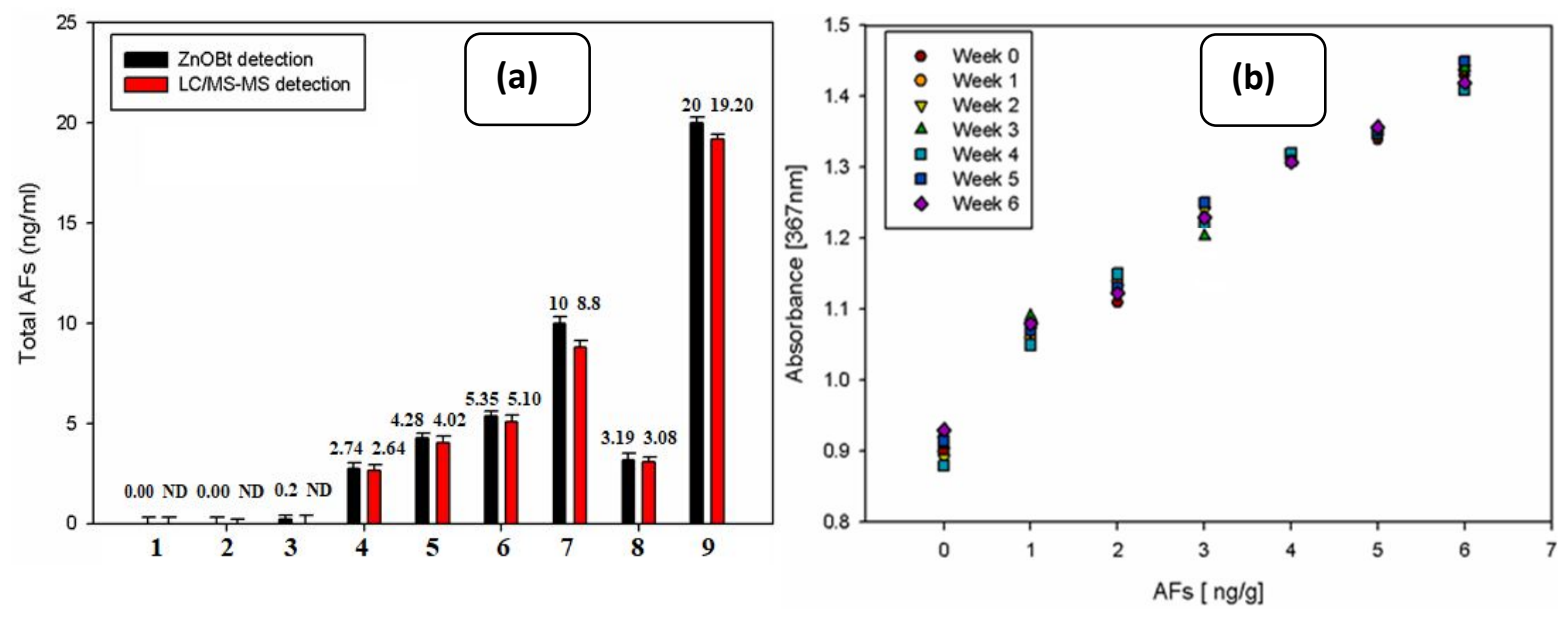

Figure S5 (a) Accuracy calculation of Zn(cur)OBt composite platform in food samples. The real value concentration was verified with standard gold technique LC/MS-MS. (b) Consistency or stability analysis over a period of one week to nine weeks at different AFs concentration from 0.1 to $7 \mathrm{ng} / \mathrm{g}$.

Table S2 CIE L*a*b* coordinates of colorimetric analysis of AFs $\left(\mathrm{AFB}_{1}+\mathrm{AFB}_{2}+\mathrm{AFG}_{1}+\mathrm{AFG}_{2}\right)$ in proportion of 1:0.1:0.3:0.03 by the $\mathrm{ZnBt}-\mathrm{Cur}$ based sensor

\begin{tabular}{|c|c|c|c|c|c|c|c|}
\hline Sample & Color & $\begin{array}{l}\text { Food } \\
\text { sample }\end{array}$ & $\mathrm{L}$ & $a^{*}$ & & $b^{*}$ & $\begin{array}{l}\text { Comparativ } \\
\mathrm{e} \\
\text { interpretatio } \\
\mathrm{n}\end{array}$ \\
\hline $\begin{array}{l}\text { With respect to } \\
\text { Reference (white } \\
\text { plate) }(n=3)\end{array}$ & White & & 94.84 & $\begin{array}{l}-0.52 \pm \\
1.2\end{array}$ & & $4.05 \pm 0.4$ & $\begin{array}{l}\text { It is most } \\
\text { light, less } \\
\text { redder and } \\
\text { more } \\
\text { yellower }\end{array}$ \\
\hline $\begin{array}{l}\text { Control } \\
\text { Unspiked corn and } \\
\text { almond extract in } \\
\text { methanol } \\
\text { ( } \mathrm{ZnOBntNCs} \mathrm{-Cur,} \\
\mathrm{NaOH} \text {, Boric Acid) } \\
(\mathrm{n}=3)\end{array}$ & Red & $\begin{array}{l}\text { Corn } \\
\text { Almon } \\
\text { d }\end{array}$ & $\begin{array}{l}20.1 \pm 2.2 \\
21.23 \pm \\
2.4\end{array}$ & $\begin{array}{l}27.9 \\
1.2 \\
28.1 \\
1.3\end{array}$ & \pm & $\begin{array}{l}17.1 \pm 0.4 \\
16.1 \pm 0.3\end{array}$ & $\begin{array}{l}\text { Control } 1 \text { It } \\
\text { is least light, } \\
\text { most red } \\
\text { and least } \\
\text { yellow than } \\
\text { Test }\end{array}$ \\
\hline $\begin{array}{l}\text { Control } \\
\text { Unspiked methanol } \\
(\mathrm{ZnOBntNCs}-\mathrm{Cur} \text {, } \\
\mathrm{NaOH}, \text { Boric Acid, } \\
\text { Methanol) })(\mathrm{n}=3)\end{array}$ & Red & & $20.9 \pm 1.7$ & $\begin{array}{l}26.7 \\
0.3\end{array}$ & \pm & $\begin{array}{l}18.1 \quad \pm \\
0.32\end{array}$ & $\begin{array}{l}\text { Control } 2 \text { is } \\
\text { less light, } \\
\text { more red } \\
\text { and less } \\
\text { yellower } \\
\text { than Test }\end{array}$ \\
\hline
\end{tabular}


Test- Spiked corn and almond extract (ZnOBntNCs -Cur

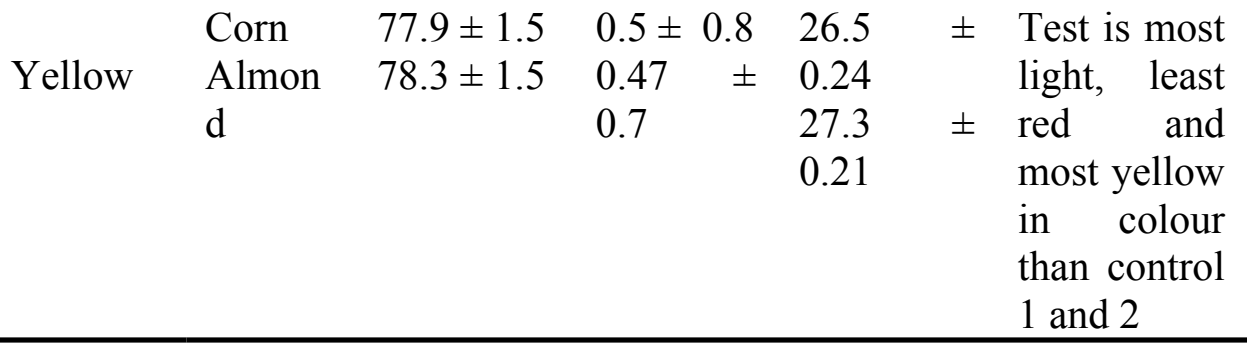

-AFs, $\quad \mathrm{NaOH}$, Boric Acid) $(\mathrm{n}=3)$ than control

Analysis of AFs by LC/MS-MS

\section{LC/MS-MS condition:}

Detection was performed with A Waters UPLC system (Waters, Milford, MA, USA) equipped with an Agilent JetStream electrospray ionization (ESI) source and a 6470 series Triple Quadrupole LC/MS (Agilent technologies, Germany. Chromatographic separation of AFs was carried out with Kinetex Biphenyl column $(50 \mathrm{~mm} \times 3 \mathrm{~mm}$ i.d., $2.6 \mu \mathrm{m}$ particle size $)$ preceded by a Security Guard TM ULTRA Holder pre-column, both supplied by Phenomenex (Phenomenex, Torrance, CA, USA). The flow rate of mobile phase was fixed to $300 \mu \mathrm{L} \mathrm{min}^{-1}$ and the injection volume for both standard and sample was $5.0 \mu \mathrm{L}$. The column oven was maintained at $40 \mathrm{C}$. For MS/MS detection, the ESI interface was used in positive polarity with the following settings: Capillary voltage, source temperature, desolvation gas flow rate, and its temperature were set at 3 $\mathrm{kV}, 120{ }^{\circ} \mathrm{C}, 600 \mathrm{~L} \mathrm{~h}^{-1}$, and $350{ }^{\circ} \mathrm{C}$, respectively. Collision-induced dissociation was performed using argon as collision gas at a pressure of $3.5 \times 10^{-3}$ mbar in the collision cell (Figure S5) [3].

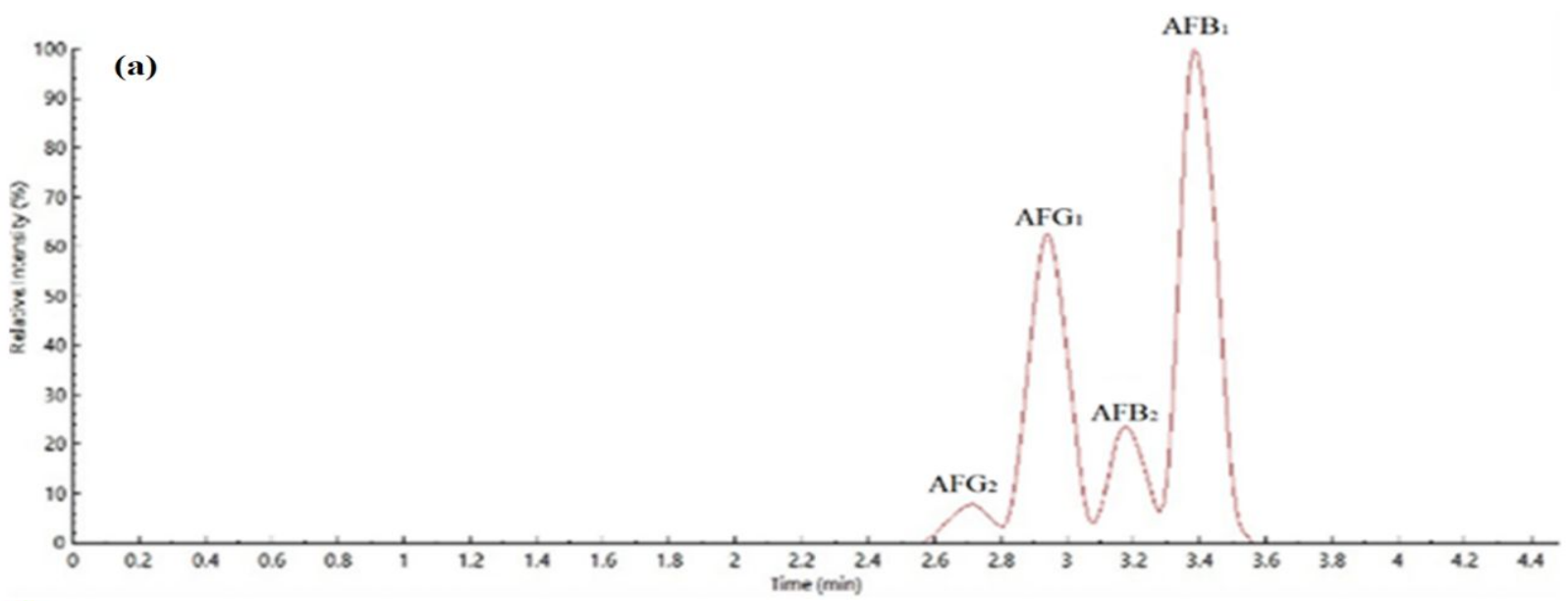

(b)

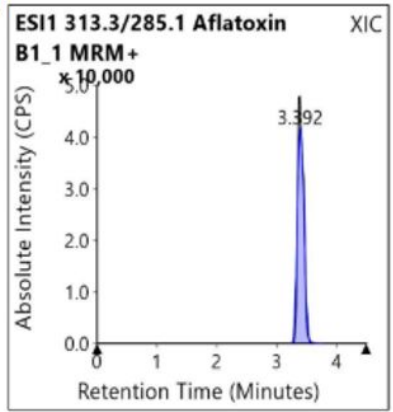

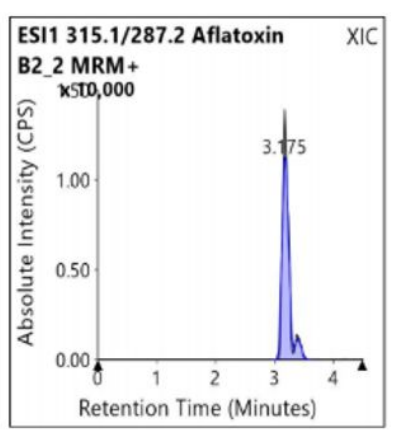
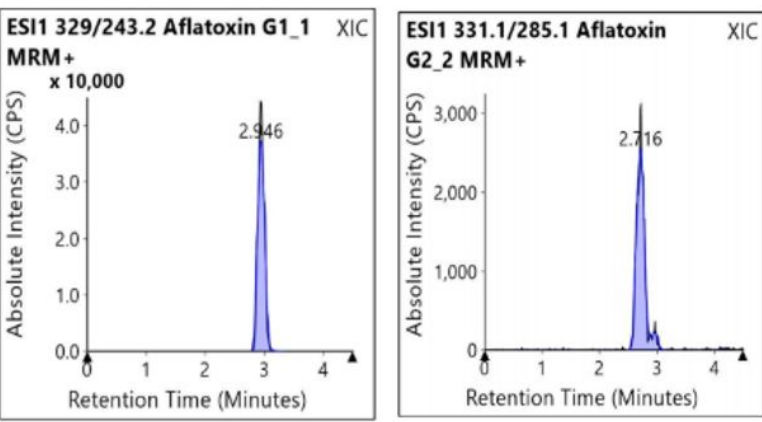
(c)
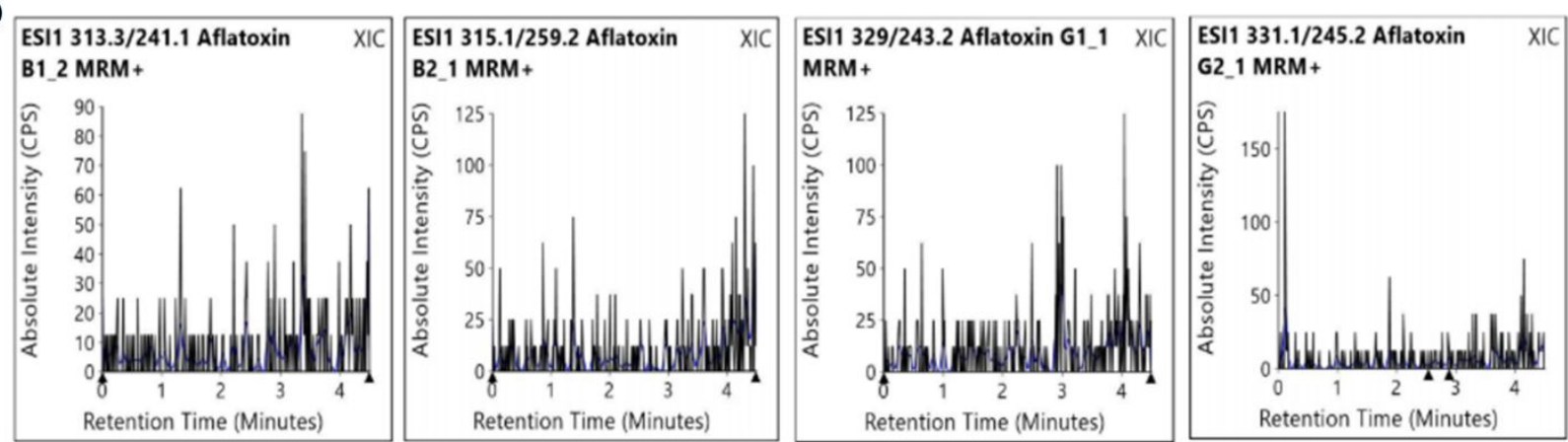

(d)
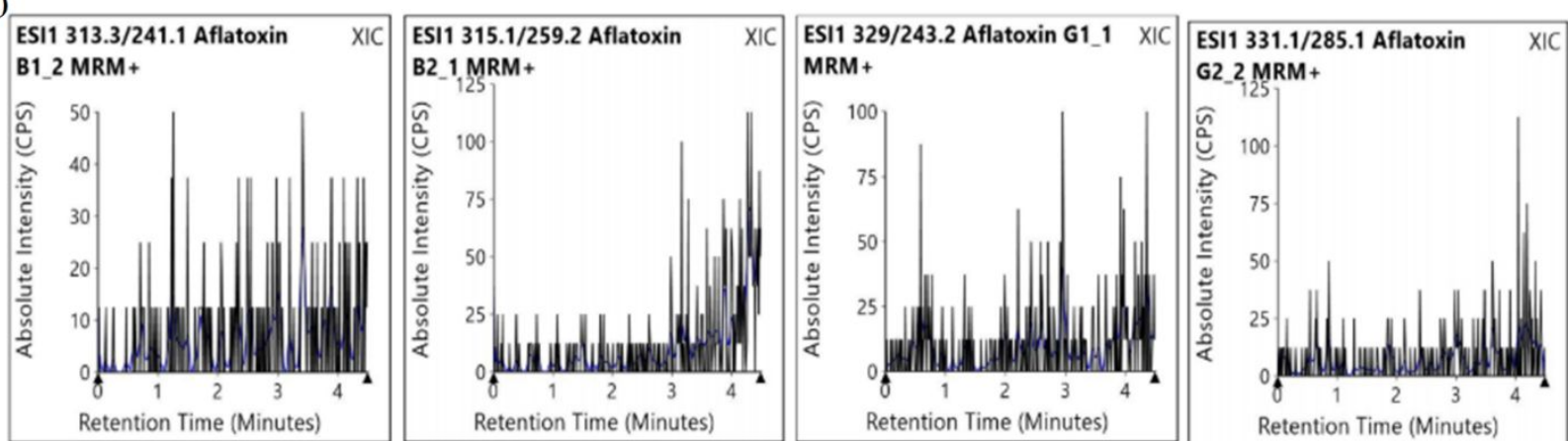

(e)
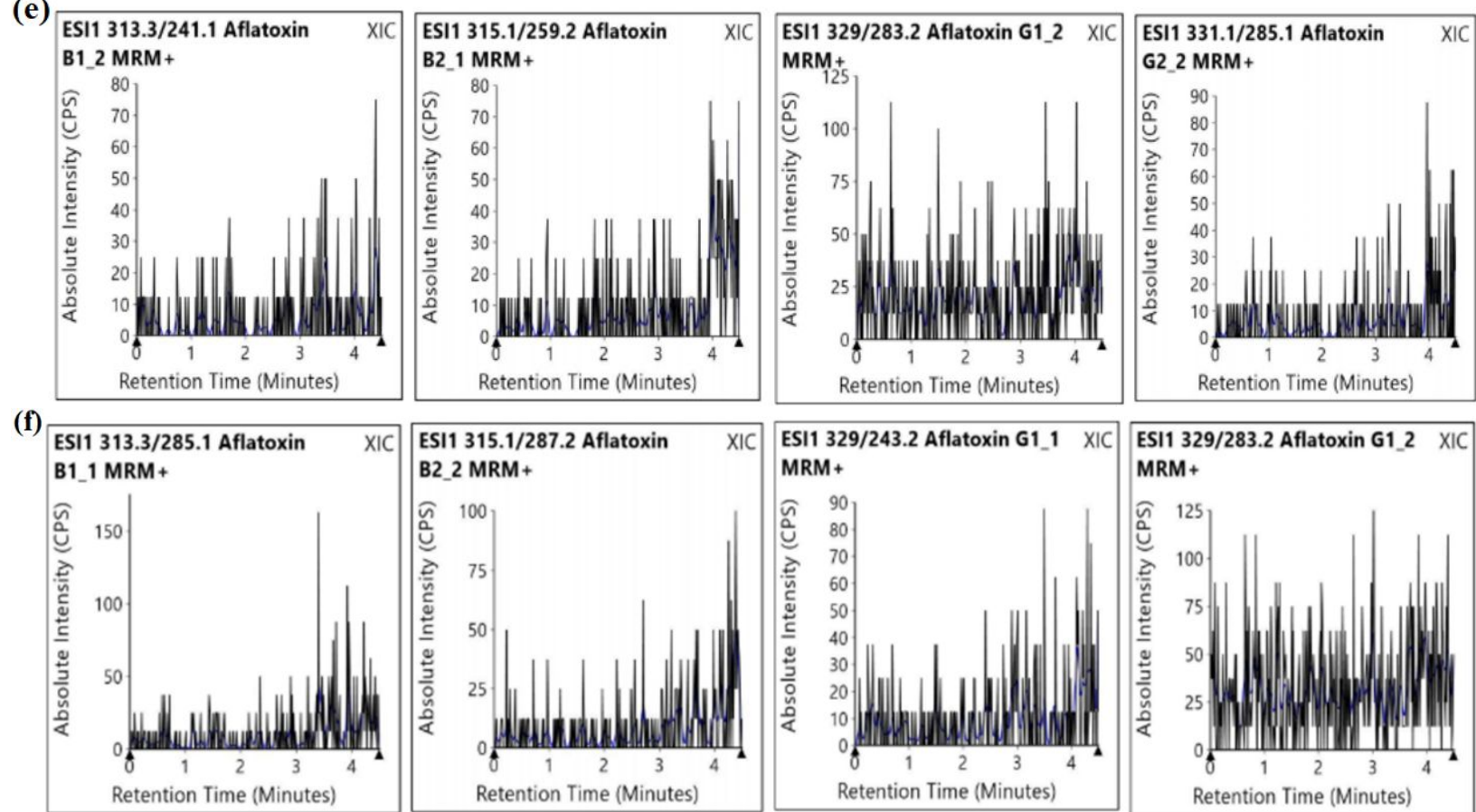

Figure S6. LC/MS-MS chromatograms of (a) AFs chromatogram (b) standard solution (5 ppb) in the ratio of 1:0.1:0.3:0.03, (c) corn sample 1, (d) corn sample 2, (e) almond sample 1, and (f) almond sample 2. Retention times were around 3.392, 3.175, 2.946 and 2.716 min for $\mathrm{AFB}_{1}, \mathrm{AFB}_{2}$, $\mathrm{AFG}_{1}$ and $\mathrm{AFG}_{2}$, respectively. No peak was present in the chromatograms of corn and almond samples, indicating that the selected food samples for addition and recovery experiments were aflatoxin-free. 


\section{REFERENCES}

1. Nones, J.; Solhaug, A.; Eriksen, G. S.; Macuvele, D. L. P.; Poli, A.; Soares, C.; Nones, J. Bentonite modified with zinc enhances aflatoxin $\mathrm{B}_{1}$ adsorption and increase survival of fibroblasts (3T3) and epithelial colorectal adenocarcinoma cells (Caco-2). J. Hazard. Mater. 2017, 337, 80-89.

2. Al-Asheh, S.; Banat, F.; Abu-Aitah, L. Adsorption of phenol using different types of activated bentonites. Sep. Purif. Technol. 2003, 33, 1-10.

3. Santis, B. De.; Debegnach, F.; Gregori, E.; Russo, S.; Marchegiani, F.; Moracci, G.; Brera, C. Development of a LC-MS/MS Method for the Multi-Mycotoxin Determination in Composite Cereal-Based Samples. Toxins 2017, 9, 169. 